\title{
An Evaluation of the Public-Private Partnership in the Lekgalameetse Nature Reserve in South Africa
}

\author{
Christopher Modise Mashale \\ University of Limpopo, Tufloop Graduate School of Leadership, Edupark, Fauna Park, \\ PO Box 759, Polokwane 0787, Republic of South Africa \\ Theresa Moyo \\ University of Limpopo, Tufloop Graduate School of Leadership, Edupark, Fauna Park, \\ PO Box 759, Polokwane 0787, Republic of South Africa \\ Oliver Mtapuri \\ University of Limpopo, Tufloop Graduate School of Leadership, Edupark, Fauna Park, \\ PO Box 759, Polokwane 0787, Republic of South Africa \\ Emai: simbaomtapuri@yahoo.com
}

\section{Doi:10.5901/mjss.2014.v5n20p855}

\section{Abstract}

In recent years Public Private Partnerships (PPP) in protected areas are becoming more popular as ways to generate income and alleviate poverty. This article examines the partnership in terms of design, implementation and sustainability of a Public Private Partnership (PPPs) project meant to develop the local community in a nature reserve. This study is qualitative and quantitative in nature, and used face to face interviews and a questionnaire to collect data. A thematic approach was used to analyse the interview transcripts while the questionnaire was subjected to appropriate statistical methods. The article argues that although the partnership was based on a mutual agreement, the benefits to the community were much less than expected. The limited success of the project is largely attributable to the unequal power relations in the partnership, coupled with capacity limitations in terms of governance and management of resources. The article concludes that a rethinking of the design of PPPS in the context of nature reserves is necessary by emphasizing the importance of the integration into PPPs, of strategies which empower communities to participate as equal partners and which also enhances their governance and management skills for co-management of nature reserves. The major contribution of this article is a model of public private partnership which espouses the following principles: symmetric power relations; learning and re-learning; inclusion; community capacity enhancing; exercise of community power; collective participation and control; collective benefits and community self management.

Keywords: Sustainable partnerships, protected areas, community development, poverty alleviation

\section{Introduction}

The Republic of South Africa is endowed with a diverse and rich biodiversity which has a great potential for economic growth and sustainable development. South Africa is rated number three in the world in terms of its biodiversity following Indonesia and Brazil (UNESCO, 1996). In order to achieve environmentally sustainable development, protected areas have been designated as a priority area for development of the domestic and international tourism industry.

Apartheid created a country with different levels of socio-economic dimensions created by policies which led to the dispossession of the majority of people from their lands for agricultural and conservation reasons. Since 1994, the South African government has pursued a development path designed to achieve social and economic transformation of the economy. Transformation aims to stimulate the economy in order to create means to improve the quality of life of all citizens and by so doing, to redress the fundamental challenges of gross inequalities in society created by apartheid. As such, Government promulgated policies which attempt to also improve the social and economic conditions of communities that are adjacent to nature reserves.

A major challenge in the country is that in most cases, nature reserves have been established without due consideration for communities adjacent to them. Such an approach has tended to marginalize instead of improving the 
livelihoods of local communities and reducing poverty. These reserves have not benefited them even though private tourist operations have profited significantly. This has created some tension between the locals and conservation agencies which affects the success of the protected area. Kepe et. al (2005) contend that addressing the immediate and long term needs of the poor, while at the same time conserving the environment is not an easy task. They explain that it requires commitment and compromise from all stakeholders where necessary. Armitage, Berkers and Doubleday (2007:4) share a similar perspective when they point out that although technical expertise is important in policy decisions regarding partnerships on natural resources, increasingly, their success depends more on negotiation and agreement among the key stakeholders who consist of government, communities and the private sector.

The state plays a major role in protecting the biodiversity of the country, promoting economic growth and sustainable development, and in implementing poverty reduction programmes that are in line with community development. The National Environmental Management Protected Areas Act (NEM: PAA) calls for the sustainable use of protected areas for the benefit of the local people should be promoted (South Africa 2003). It mandates the government together with its national and provincial tourism and conservation agencies to promote both biodiversity conservation and rural development. In the case of Lekgalameetse Nature Reserve, the Public Private Partnership was established precisely to pursue such developmental goals. Wolmer and Ashley 2003:34-39 reinforce this idea when they argue that it is the responsibility of the state to create maximum benefits for communities next to nature reserves, especially in cases where they have rights over land and where the state controls competitive sites as this creates hope for improving rural livelihoods.

\section{Background}

Partnerships are defined in different ways in the literature. They are seen as a kind of relationship, joint management, collaboration between parties. Bramwell and Lane (2000) define a partnership as regular, cross-sectoral interaction over an extended period of time between parties, based on at least some agreed rules or norms, intended to address a common issue or to achieve a specific policy goal(s), which cannot be solved by the partners individually and involving pooling and sharing of appreciations or resources, mutual influence, accountability, commitment, participation, trust and respect and transparency. Despite the variety of terms used, the core elements of a partnership are that it involves a relationship among stakeholders, where some kind of pooling of resources, time and energy occurs to achieve similar goals (Bramwell \& Lane, 2000; Gray, 1985; Selin \& Chavez, 1995).

Partnerships exist at different levels and take different forms, but they have in common the expectation that the participants can achieve their objectives more effectively and efficiently through strategic alliances with others rather than acting independently. This 'collaborative advantage' (Huxham and Vangen, 2000) is attained by pooling complementary resources and sharing risks and rewards in the joint undertaking (Warner and Sullivan, 2004). Collaboration with a wide range of stakeholders can facilitate a move towards sustainable tourism (Bramwell \& Lane, 2000; de Lacy, Battig, Moore, \& Noakes, 2002).

The current land debate in South Africa has implicated existing private companies as claims are made on some parts of their land. The apartheid system in South Africa created a situation in protected areas were often strictly fenced off, with little or no positive interaction between protected areas and adjacent communities. Adjacent communities were restricted from gathering customary resources such as traditional food, firewood for fuel/energy and medicinal plants as it was considered to be illegal. Communities had an opportunity to claim their land in terms of the Restitution of Land Rights Act (No 22 of 1994 as amended) in which most of the protected areas were affected. The act provides for the restitution of land rights to communities which were dispossessed after 1913 as a result of discriminatory laws that were executed without compensation.

Successive democratic governments believed that co-management in a form of partnerships should be the preferred option in terms of land claims. The People and Parks programme prioritized land restitution in protected areas as its main focus, which culminates in co-management, access and benefits sharing including community-public-privatepartnership (PPP) models. These models are aimed at balancing the objective of biodiversity conservation with increased local economic development and poverty alleviation. Wolmer and Ashley (2003:37) are of the view that the right of participation in protected area management will increase with ownership. With the current heated land debates in South Africa, it is in most cases difficult to balance the interest of communities and conservation agencies when land is set aside for conservation (de Villiers 2008). The models of community-based or pro-poor tourism being promoted as development options have very limited, and very mixed pedigree and it remains to be seen whether they can deliver the anticipated benefits. 'If they fail to succeed on sufficient scale, or if the benefits are not widely distributed within communities, the pressure for direct access to land for subsistence that drove many of these claims in the first place is 
likely to resurface (Lahiff2002:20).

Carruthers (2007:296-297) argues that protected areas are widely viewed as cash cows for economic development and service delivery, rather than biodiversity protection or ecosystem services luxuries. As a result, there have been cases of conflicts often resulting in destruction of environmental resources. Over and above the incentives faced by particular organisations to participate, the proliferation of partnerships can be interpreted as part of a broader shift in governance, or the process of giving 'direction to society' (Rhodes, 1997) through the interplay between government, business and civil society. Partnerships can sometimes be seen as a new model of governance, referred to as 'new', 'collaborative' or 'network' governance, among other terms (Moon, 2002; Donahue, 2004; Ruggie, 2002).

The private and public institutions realised the need to forge close relationships with communities adjacent to their projects in protected areas by involving them in conservation activities to allow the benefits to flow to the communities. Ojwang, (1999) acknowledges that through integrating the local communities into these projects, private and public institutions are fulfilling a social responsibility of creating development opportunities for the impoverished rural communities adjacent to their projects and thus view their contract partnership with the communities as a tool for rural development.

The government views partnerships as a mechanism for facilitating the social and economic empowerment of rural communities. The government of South Africa acknowledges that in addition to other sectors, the conservation industry has a significant role to play in rural development (DEAT, 1996). The industry considers the government's role as that of creating an enabling environment for the development of the sector in a way that is equitable and sustainable. Benner et al, ( 2004) argue that partnerships are being established as a response to gaps in traditional governance models, especially with regard to the limited - and some argue declining - ability of states to devise and implement rules or to provide public goods in the increasingly global and complex interactions between social, economic and environmental systems.

\section{Literature Review}

There are a number of partnership formations or methods that can be used in protected areas or nature reserves, depending on the level and kind of venture and the benefits thereof. In this study we are only going to concentrate on one model of partnerships which is common in protected areas in the Southern African region, which is co-management. Comanagement is occasionally referred to as participatory, collaborative or joint management (Berkes and Henley 1997:29; Kepe 2008:314).

There are many definitions of the term 'co- management' but it is commonly regarded as a middle-range management option between state and community management (Isaacs and Mohamed 2000) which suggests and encourages participatory democracy, power sharing, local incentives for local use of natural resources, and decentralisation of resource management decisions (Kepe 2008). Greater participation by resource users and landowners in management activities and the integration of local values and knowledge in decision-making processes are recognised as necessary and beneficial (Berkes and Henley 1997:31; Hauck and Sowman 2005:2). In the year 2007, the Department of Land Affairs and Department of Environmental Affairs and Tourism signed a Memorandum of Agreement (MoA) which led to the cooperative national approach to the resolution of land claims in protected areas (South Africa 2007). The use of the co-management method was considered the best strategy in the MoA to reconcile land restitution in protected areas (Kepe 2008:312).

The dawn of a new democracy country in 1994 led to a number of new policies and laws for natural resource management influence by international debates and trends which supported the principles of equity, social justice, participation, environmental sustainability, accountability and transparency (Hauck and Sowman 2005). Co-management is described in Section 42 of NEM (South Africa 2003).

Normally, the right of participation in protected area management increases with land ownership (BorriniFeyerabend et al 2000:24; Turner et al 2002:3). The management capacity of the landowners also determines the level of participation. Landowners also have to choose how much they can/want to invest in co-management, and thus how much risk they are willing to take. According to Berkes (1997:6), co-management is feasible only if at least four conditions are met. These are the presence of appropriate institutions, trust between partners, legal protection of local rights, and economic incentives for local people. Due to land restitution, land ownership in protected areas in South Africa often changes from state land to private land and therefore this feature needs to be taken into consideration, as it influences the resource and land rights.

In South Africa cooperative co-management is promoted as the preferred settlement option within the land restitution process in protected areas. A recent example is the joint conservation management initiative of the Makuleke 
region of the Kruger National Park by the government and the community. Private investors are expected to join the partnership for further development of the area. The community now owns the land after a highly successful claim from the Kruger National Park through negotiations (Koch and Massyn, 1999).

Isaacs and Mohamed (2000:2) are of the view that 'The ability to move beyond the limitations of either state, private or community management is seen as a key benefit of co-management'. Increasingly, co-management is seen as an alternative to resource management that joins the interests of government (to achieve efficiency and sustainability) with those of landowners and resource users (who have concerns for self-governance, active participation and a variety of livelihood issues) (Hauck and Sowman 2005). In this case, co-management was being implemented.

\section{Methodology}

This article used essentially a qualitative approach. Such an approach was deemed appropriate in order to gain insight into the partnership agreements and relationships. Face to face interviews with a number of villagers and other key stakeholders were undertaken. A qualitative method relying on in-depth interviews provides a way of collecting information on the knowledge, values, opinions, attitudes and experience of the target group (Neuman 2000). This allows participants to speak about their experiences in their own terms and words. As it is common, qualitative approaches are relevant (Wilson \& Little, 2005), this means relying on rich, thick descriptions and quotes from the interview scripts (Hollinshead, 2007).

In-depth interviews were used and interview sessions were arranged with respondents concerned. The researcher also used questionnaires to collect data on the impact of the public private partnership, the benefits as well as developmental issues of concern. The sample was selected using purposive sampling. Preference was given to key informants, that is, participants actively involved in the partnership and people who were part of the community partnership forum. A sample of 40 people was selected comprising people from reserve management, the Limpopo Tourism Agency (LTA), Limpopo Department of Economic Development Environment and Tourism (LEDET), community leaders, thirty community members and two co-management members. Of particular importance was the reserve management which has insight into the daily activities which were taking place between the reserve and the surrounding communities; the Limpopo Tourism Agency and LEDET managers are responsible for facilitating the partnership, while the co-management members represent the communities concerned regarding management issues of the nature reserve and the community members as key stakeholders.

In-depth interviews were used to obtain information from interviewees, namely LTA, LEDET and Trust committee members. According to Kumar (2005), "one of the main advantages of a structured interview is that it provides uniform information, which assures the comparability of data". Self-administered questionnaires with questions that allowed community members to fully express themselves and give detailed information were used and distributed to them during community meetings which are held on monthly basis in their respective villages with their chiefs. Texts, views, expressions and opinions were analysed using content analysis as it is one of the most appropriate methods under the circumstances for qualitative data. Each interview was coded soon after transcription. An emergent, interpretive approach was adopted to provide a framework for transcript analysis and theme development (Neumann, 2000; Strauss \& Corbin, 1998).

\section{Results and Discussion}

According to the interpretive analysis of the stakeholder interviews, three key themes emerged which defined the nature and quality of the partnership between the government and communities adjacent to the LNR. The themes relate to; (a) partnership development and management, (b) stakeholder benefits, and (c) sustainability.

The land claim was lodged in 1996 and was facilitated by government departments headed by the regional land commissioner. The communities were encouraged to claim their land for compensation and benefits attached to the land claim. The intention for the land claim was for restitution, because the land is declared a protected area making physical occupation of the land was impossible. According to members of the co-management, the management is still struggling to be serviced in terms of agricultural activities as part of the land is for agricultural purposes. Members of the comanagement expressed the view that they experienced many challenges during the process of lodging a claim but received the support of the land commissioners. In compliance with the National Co-management Framework, they meet quarterly to discuss issues affecting the LNR and also said that the partnership is gaining momentum and that they understood the challenges much better. However, there was a sense that there is a lack of coherence between land ownership and biodiversity management as there was evidence of some confusion on the expectation of the communities 
and frustration on the part of the management agency of the nature reserve on what each should do. According to the LNR Strategic Plan (2013-2018), there is evidence that the management agency of the nature reserve and the communities agreed on erecting a new fence to manage livestock and poaching from taking place in the nature reserve. This suggests that stakeholder consultation and support is an important aspect of effective protected area management as misunderstanding can easily scuttle the project. It is also a requirement in terms of Sections 39(3) and 41(2)(e) of the National Environmental Management: Protected Areas Act, 2003 (Act No. 57 of 2003).

A majority of the respondents agree that they were involved in the partnership from the onset. This implies that there was meaningful participation from the beginning of the PPP. While job opportunities in the community were mostly offered by commercial farming ventures comprising both temporary and permanent employment, migration to urban areas for employment purposes was widespread due to limited opportunities in the area manifesting in a high unemployment rate. Respondents complained that their objectives centred on employment creation, opportunities for firewood collection and grazing of their livestock more than anything which were largely being unmet. Therefore, the expectation was that the partnership should impact livelihoods in terms of job creation and spaces for grazing and firewood collection. The limited number of people who were benefiting from the partnership were those who, essentially, were indirectly employed which meant that their future was not guaranteed as they depended on occasional work which is provided by the nature reserve.

The interview data sourced from members of the LNR Co-management committee provided an understanding of whether there were benefits accruing to the community and issues of sustainability and impacts. It emerged that many community members were being employed in land care programmes such as Working for Water and Expanded Public Works Programme (EPWP). This was an indication that these programmes have the capacity to employ about 70 people on seasonal basis in the nature reserve. The committee members were also of the view that more can be done in terms of effectively involving the communities in equity partnership and concessions opportunities. However, the partnership has not created adequate jobs to cater for the adjacent communities as community members were not given preference regarding permanent employment and huge development projects/tenders in the nature reserve.

Additional information gathered from the respondents suggests that LNR through its co-management committee, conducts annual assessments on beneficiation and sustenance of the partnership in relations to the socio-economic impact in the adjacent communities. It was stated that the management authority is not effectively implementing decisions that are taken in the co-management meetings suggesting that there is tension in the management processes of the project.

Further analysis, based on the data collected and general comments made by respondents, it can be adduced that the majority of the surrounding community members, in general, welcomed the partnership process and have confirmed that this partnership has the potential to bring about change in terms of how they look at conservation and management of a protected area.

Evidence shows that a larger number of the participants in this partnership is adults and pensioners as compared to the youth. This may work against efforts to build this community because for sustainable community development to take place, all the stakeholders in the community must be involved especially the youth for them to be able to sustain the legacy. A number of community leaders, who were involved in the partnership formation, spoke of the partnership formation process as "frustrating", "complex" and "time-intensive". Such that some of the community members lost interest in the partnership before the implementation process was concluded. Some of the claimants "say they were not involved in the partnership in the initial stages due to the fact that they are replacing family representatives who are no longer available due to ill health or have passed on".

The management agency also said that most of the community members do not understand the implications of managing a protected area and the legislation involved in creating such a partnership.

While the process of preparing and lodging of land claims was exhausting, the claimant's spoke of the helpfulness of the Department of Rural Development and Land Affairs, and the Land Commission in assisting with information and the process of how to lodge claims. "The Land Commission were of great support and help in terms of information and guidance we needed when lodging a claim for our land" (Claimant"). Justifiably, claiming of a protected area must conform to the National Environmental Management of Protected Areas Act. Ironically, the act restricts claimants from physical occupation of the land as most claimants were of the view of using the land for physical occupation, farming and grazing. The formation of the partnership was drastically delayed due to lack of knowledge and desperation of farming and grazing land.

As such, the respondents were of the view that government is biased resulting in their wishes being sidelined. For instance, they claimed that the nature reserve should create more employment opportunities, increase allowance for firewood collection, and grant them permits which would allow their livestock to graze in the protected area. The 
communities and the management agencies came to the common understanding that a land claim of a protected area is not like any other land claim were claimants can decide what to do with the land after a claim is successful. Hence, the partnership was formed and gave the adjacent communities an opportunity to become stakeholders in the development and management of the LNR.

The day-to-day management of these engagements created new challenges for stakeholders, particularly regarding issues related to employment and access to resources in the LNR. The majority of the respondents were unemployed and with little influence on the employment of community members. In some cases, adjacent communities felt that they should be given preference when it comes to tendering and employment opportunities. Their frustration is encapsulated in the following excerpt: "LNR management hires outsiders even though it is manual job that can be performed by people residing in the surrounding communities" (Claimant).

There were cases where LNR gave tenders to the local people. This meant nothing to local people as they claimed that the big contracts are given to outsiders. One respondent said "from a business point of view it is useless to give a contract to an outsider who comes with his own people to work in our nature reserve, whilst we have people who are capable to do the job for less".

Some respondents were generally satisfied with the partnership and credited it for its role in local economic development. However, the employment figure shows that the majority of the society in the adjacent communities is economically inactive. Theyr believe that there is a very strong correlation between the PPP and their economic growth which can be achieved with resources sharing and additional income accruing in form of contracts.

The evidence also indicated a strong link between partnership development, and governance (management) and sustainability of socio-economic and environmental issues of the nature reserve. The effectiveness of the LNR partnership is still questionable because the governance and benefits issues of the nature reserve are not clearly articulated and understood by all stakeholders especially from representatives of the management agency and the community by their own admission.

From the data that is available, there is proof that the partnership was developed and implemented in a professional and harmonious way. However, the community representatives in the co-management team are of the view that what is agreed upon in their meetings is not implemented by the representatives of the management agency (LTA and LEDET).

Members of LTA and LEDET management considered the partnership to have succeeded in improving management of the protected area. Admittedly, the relationship between the management of the nature reserve and the community has improved and the Community Property Association is of the same sentiments with regard to the management of the nature reserve.

The fact that the land claim process went well and that the management agency for the nature reserve and the claimants formed a co-management agreement is important. This meant that the community is ready and willing to work with government to continue protecting the natural resource in that area. Both the management agency (LTA/LEDET) and the community representatives must work very hard to make sure that challenges that are experienced are ironed out.

\section{Towards a Model of Partnership in Protected Conservation Areas}

Given the situation in the LNR, we posit a model for Private Public Partnership which supports:

- Symmetric relations - because co-management assumes two or more stakeholders, the power relations should be level to ensure genuine engagement for the common good;

- Learning and re-learning - there are lessons to be learned from the engagements. This means that stakeholders must be willing to learn and re-learn in order not to commit mistakes previously encountered;

- Inclusion - the engagements must be inclusive of the adults, the youth; the community and implementing partners and so forth, without alienating any other party;

- Community capacity enhancing - the engagement should enhance the community's capacity to lead and manage themselves and their projects;

- Exercise of community power - in their collective, communities must exercise power through their structures which give precedence to their needs and priorities;

- Collective participation and control - control must reside in communities to encourage participation of community members as the resources belong to all.

- Collective benefits - benefits must accrue to the largest number in the community and as such eliticism should be discouraged. 
- Community self management - is elaborated in Table 1 below. It shows the advantages and disadvantages of co-management arrangements versus community self management.

Table 1: Co-management and community self management

\begin{tabular}{|l|l|}
\hline Co-Management & Community Self Management \\
\hline Give instructions to communities & Communities self rule and govern which raises their self awareness \\
\hline Creates community subservience & Community are in control of their destiny and projects \\
\hline Disempowers communities & Empowers communities \\
\hline $\begin{array}{l}\text { Can cause social and cultural conflicts over jobs and } \\
\text { resources }\end{array}$ & $\begin{array}{l}\text { Conflicts over jobs between locals and outsiders are avoided. This does not mean } \\
\text { that conflicts within will be eliminated. }\end{array}$ \\
\hline Creates its own level of bureaucracy & A layer of bureaucracy is removed in self governance. \\
\hline Encourages eliticism & Eliticism may be avoided depending on how the arrangements are configured. \\
\hline
\end{tabular}

\section{Source: Authors}

In cases of community self management, there is potential for communities to be independent both economically and financially through the exercise of community power in decision making. Community self management also facilitates collective management of community resources through nurturing leadership which avoids the exploitation of locals and encouraging community entrepreneurship. The assumption of control and ownership by communities enhances their selfesteem and sovereignty. However, some of the disadvantages of community self management and ownership include the removal of the incentive to work as an individual and creation of dependency.

\section{Conclusions and Recommendations}

In line with the findings, Brawell and Lane (2000) are of the view that collaboration with a wide range of stakeholders can facilitate a move towards sustainable tourism. The partnership that is created in the LNR and other protected areas that are under land claims, should be able to address the socio-economic issues of all stakeholders and move beyond the thinking of land owners and management agencies. However, it is important to acknowledge that communities will always have higher expectations when ever partnership of this nature is formed especially due to their social and economic background and historicity associated with land ownership in South Africa. While the management agency must continue with their legislative mandate of the protection of biodiversity that is found in the LNR without compromise it should be inclusive in its decision making processes, involve the communities in the design and implementation of economic programs beneficial to them and understand the needs of the local community in terms of culture and traditions. As such

It is imperative for the management agency to fast-track the issue of involving private partners for developmental purposes as the process to bid for the development of the economic hubs within the precinct of the nature reserve is long overdue.

The settlement and co-management agreements, together with the management plan, should be able to provide the framework for coordinated and proper management. This will avoid unnecessary tension between stakeholders. The management agency should implement a capacity building initiative on co-management, tourism and conservation. The management agency is an equal co-management partner with the claimants and therefore should not intervene in the internal business of the land claimants and vice versa.

\section{References}

Armitage, D., Berkes, F \& Doubleday, N. 2007. Introduction: Moving beyond co-management, In D. Armitage, F. Berkes and N. Doubleday. Adaptive co-management: Collaboration, learning and multi-level governance. Vancouver: UBC Press.

Benner, T., Reinicke, W.H. \& Martin Witte, J. 2004. Multisectoral Networks in Global Governance: Towards a Pluralistic System of Accountability, Government and Opposition, 39( 2): 191-210.

Borrini-Feyerabend, G., Farvar, MT., Nguinguiri, JC., \& Ndangang, V. 2000. Co-management of natural resources: Organising, negotiating and learning-by-doing. GTZand IUCN. Heidelberg: Kasparek Verlag.

Bramwell, B., \& Lane, B. 2000. Tourism collaboration and partnerships: Politics, practice and sustainability. Clevedon: Channel View Publications.

Bryman, A. 2001. Social Research Methods, Oxford University, New York.

Carruthers, J. 2007. South Africa: A world in one country: Land restitution in national parks and protected areas. Conservation and Society, 5(3):292-306. 
DEAT, 2004. People and Parks workshop: Conservation for the people with the people 25 -27 October 2004, Swadini Forever Resort, Blyde River Canyon, Mpumalanga.

DEAT, 2006. People and Parks conference: Conservation for the people with the people 29-31 October 2006. Beaufort-West, Western Cape.

Donahue, J.D. 2004. On Collaborative Governance. Massachusetts: Harvard University Press.

De Lacy, T., Battig, M., Moore, S., \& Noakes, S. 2002. Public private partnerships for sustainable tourism. Gold Coast: CRC for Sustainable Tourism.

Gray, B. 1996. Cross-sectoral partners: Collaborative alliances among business, government and communities. In Huxham, C. (Ed.), Creating collaborative advantage. London: Sage. 57-79.

Hauck, M. \& Sowman, M. 2005. Guidelines for implementing coastal and fisheries co-management in South Africa: subsistence fishing co-management and capacity building programme. Rondebosch: University of Cape Town.

Huxham, C. \& Vangen, S. 2003. Enacting Leadership for Collaborative Advantage: Dilemmas of Ideology and Pragmatism in the Activities of Partnership Managers', British Journal of Management, 14: 61-76.

Kepe, T. 2008. Land claims and co-management of protected areas in South Africa: Exploring the challenges. Environmental management, 41:311-321

Koch, E \& John Massyn, P. 1999. Challenging Eden: From Rhetoric to Action in Community Public Private Partnerships. Cape Town: Oxford University Press.

Lahiff, E. 2002. Land reform in South Africa: an overview, with particular reference to protected areas. Programme for Land and Agrarian Studies. Cape Town: University of the Western Cape.

Ojwang, A. 1999. The Socio-Economic Impacts of Contract Timber Farming on Rural Women: A Study of Small Scale Growers in KwaZulu-Natal. Unpublished MA Thesis,University of the Witwatersrand.

Ruggie, J.G. 2002. The Theory and Practice of Learning Networks: Corporate Social Responsibility and the Global Compact, Journal of Corporate Citizenship, 5: 27-36.

Selin, S., \& Chavez, D. 1995. Developing a collaborative model for environmental planning and management. Environmental Management, 19(2), 189-195.

Turner, S., S. Collins \& B. Baumgart, 2002. Community based natural resources management: experience and lessons linking communities to sustainable resources use in different social, economic and ecological conditions in South Africa. Programme for Land and Agrarian Studies Research Report No 11. Cape Town: University of the Western Cape.

UNESCO MAB, 1996. Biosphere reserve: the Seville strategy and the statutory framework of the world network. Paris: UNESCO MAB.

Wolmer, W. \& Ashley, C. 2003. Part II: Resources and Policies. 3. Wild resources management in southern Africa: Participation, partnerships, eco regions and redistribution. IDS Bulletin 34(3).

\section{Legislation}

South Africa (Republic). 1996. The Constitution of the Republic of South Africa, 1996.

South Africa. 2003. National Environmental Management: Protected Areas Act no 57 of2003. Pretoria: Government Printer.

South Africa. 2007. Memorandum of agreement between the Minister of Agriculture and Land Affairs and the Minister of Environmental Affairs and Tourism. Pretoria: Government Printers. 